\title{
Identity of a newly isolated human polyomavirus from a patient with progressive multifocal leucoencephalopathy
}

\author{
ANNE M. FIELD, SYLVIA D. GARDNER, R. A. GOODBODY, AND \\ M. A. WOODHOUSE ${ }^{1}$ \\ From the Virus Reference Laboratory, Central Public Health Laboratory, Colindale, London, and the \\ Department of Morbid Anatomy, Southampton Group Pathology Service, General Hospital, Southampton
}

SYNOPSIS Isolation of a strain of polyomavirus, designated COL, from the brain of a patient with progressive multifocal leucoencephalopathy is described. The COL strain is antigenically similar to JC polyomavirus, previously isolated from a brain affected by progressive multifocal leucoencephalopathy and is unrelated to BK, another human polyomavirus isolated from urine. Immunological cross testing of viruses in the Polyomavirus genus shows that there are at least six antigenic types in this group.

Viruses seen in human brain in the rare demyelinating condition progressive multifocal leucoencephalopathy (PML) (ZuRhein and Chou, 1965) belong to the Polyomavirus genus of the family Papovaviridae (International Committee on Nomenclature of Viruses, 1971). In 1971 Padgett, Walker, ZuRhein, and Eckroade isolated JC polyomavirus from an infected brain and later Weiner, Herndon, Narayan, Johnson, Shah, Rubinstein, Preziosi, and Conley (1972) isolated two viruses closely related to simian virus $40\left(\mathrm{SV}_{40}\right)$ from the brains of two further patients. Another human polyomavirus, BK, was isolated from urine of a renal transplant patient who had no clinical signs of progressive multifocal leucoencephalopathy (Gardner, Field, Coleman, and Hulme, 1971) and recently four more BK strains have been isolated from urines of similar patients (Coleman, Gardner, and Field, 1973). Until recently there was no comparison of the antigenic nature of $\mathrm{JC}$ and BK viruses although both had been cross tested with $\mathrm{SV}_{40}$ virus. The recent report shows little or no antigenic relationship between JC, BK, and $\mathrm{SV}_{40}$ viruses although cross reactions occurred when hyperimmune sera were used (Penney and Narayan, 1973). This paper describes the isolation of a further polyomavirus, designated $\mathrm{COL}$, from the brain of a patient with progressive multifocal

'Present address: The County Laboratory, Glyde Path Road, Dorchester

Received for publication 8 February 1974. leucoencephalopathy and the antigenic relationships between the new strain COL, BK, JC, $\mathrm{SV}_{40}$ and the other established members of the Polyomavirus genus.

\section{Case Report}

\section{CASE HISTORY}

This 57-year-old man had been suffering from giant follicular lymphoma for about four years, the original diagnosis having been made by cervical lymph node biopsy. Treatment had included DXR, chlorambucil, and latterly prednisone $30 \mathrm{mg} /$ day. Four months before death he developed progressive visual impairment, difficulty in verbal expression, and gradually became completely blind, demented, and hemiplegic.

Investigations carried out about two weeks before death showed a normal plain skull radiograph with central pineal gland. His $\mathrm{Hb}$ was 9.7 per $100 \mathrm{ml}$. The white cell count was 3600 per cmm with $80 \%$ neutrophils. The platelet count was 30000 . The blood glucose was $116 \mathrm{mg} \%$; the urea nitrogen and electrolytes were normal. The glutamic oxalacetic transaminase was 46 units, alkaline phosphatase $5 \mathrm{KA}$ units, and the total bilirubin $3.1 \mathrm{mg}$ per 100 $\mathrm{ml}$. The Wassermann reaction was negative.

\section{NECROPSY FINDINGS}

The body had not been refrigerated and necropsy was performed 12 hours after death. 
On external examination there were small areas of bruising all over the body and there was a very slight icteric tinge.

Internally there was a moderate degree of pulmonary oedema and congestion with small subpleural haemorrhages. In the left lower lobe there was a moderate bronchopneumonia. The liver weighed $2000 \mathrm{~g}$ but was macroscopically unremarkable. The testes were macroscopically normal but there was a small hydrocoele into which some haemorrhage had occurred. The adrenal glands were a little small, but otherwise unremarkable. The spleen weighed $200 \mathrm{~g}$, with a soft, dark cut surface in which no pattern could be seen. No enlarged lymph nodes could be found anywhere in the body.

Histological examination showed a patchy bronchopneumonia. The liver showed congestion, centrizonal necrosis, and collections of lymphocytes in the parenchyma and portal tracts, consistent with residual lymphoma, but no follicle formation could be seen. Kidneys showed non-specific collections of lymphocytes in the cortex. The lymph nodes and spleen were congested and oedematous but there was no evidence of follicular lymphoma.

The weight of the unfixed brain was $1450 \mathrm{~g}$. The fixed brain was symmetrical, pale in colour, and firm in consistency with some compression of the cerebral convolutions. Coronal slices showed a symmetrical but small ventricular system. The grey matter was macroscopically normal in the frontal and parietal lobes but showed small areas of softening in the occipital lobes. The white matter of the posterior parietal left temporal lobe and both $\stackrel{0}{\vec{\sigma}}$ occipital lobes showed an ill defined diffuse softening and degeneration. No changes were seen in the $\stackrel{\vec{S}}{\rightarrow}$ cerebellum, pons, and medulla. Histological examination showed complete destruction of myelin sheaths in the deep white matter of the parietal, $\frac{\bar{\omega}}{\vec{\sigma}}$ temporal, and occipital lobes. Beneath the cortex, in $\stackrel{\varnothing}{\circledR}$ the basal ganglia, brain stem and cerebellar peduncles there were foci of demyelination. The lesions were characterized by a marked degree of fibrillary astrocytic gliosis with frequent bizarre giant astro- $\vec{\omega}$ cytes showing twisted hyperchromatic nuclei and $\stackrel{\omega}{\circ}$ numerous foamy phagocytes. Marginally they con-용 tained cells with large rounded paler nuclei of $N$ homogeneous but basophilic appearance almost is certainly representing abnormal oligodendroglia. $\omega$ Occasional oligodendroglia contained amphophilic $\triangleq$ intranuclear inclusions. Axons were relatively pre- 옥 served in the demyelinated white matter but some swelling and fragmentation was apparent. The cerebral cortex was largely intact.

Thin slices of brain tissue were fixed in glutaralde- $\vec{\varphi}$ hyde at necropsy and further processed several $\not$ days later: the tissue was postfixed in osmium tetroxide, dehydrated, and embedded in an aralditeepon mixture. Ultrastructural studies of thin sections showed that glial cell nuclei were the best preserved tissue elements and many contained round virions $39.1 \mathrm{~nm}$ in diameter and filamentous forms $23.0 \mathrm{~nm}$ across arranged singly, in strands, or in whorls. Occasional circular virions were also seen grouped together or associated with membranes in the cyto-

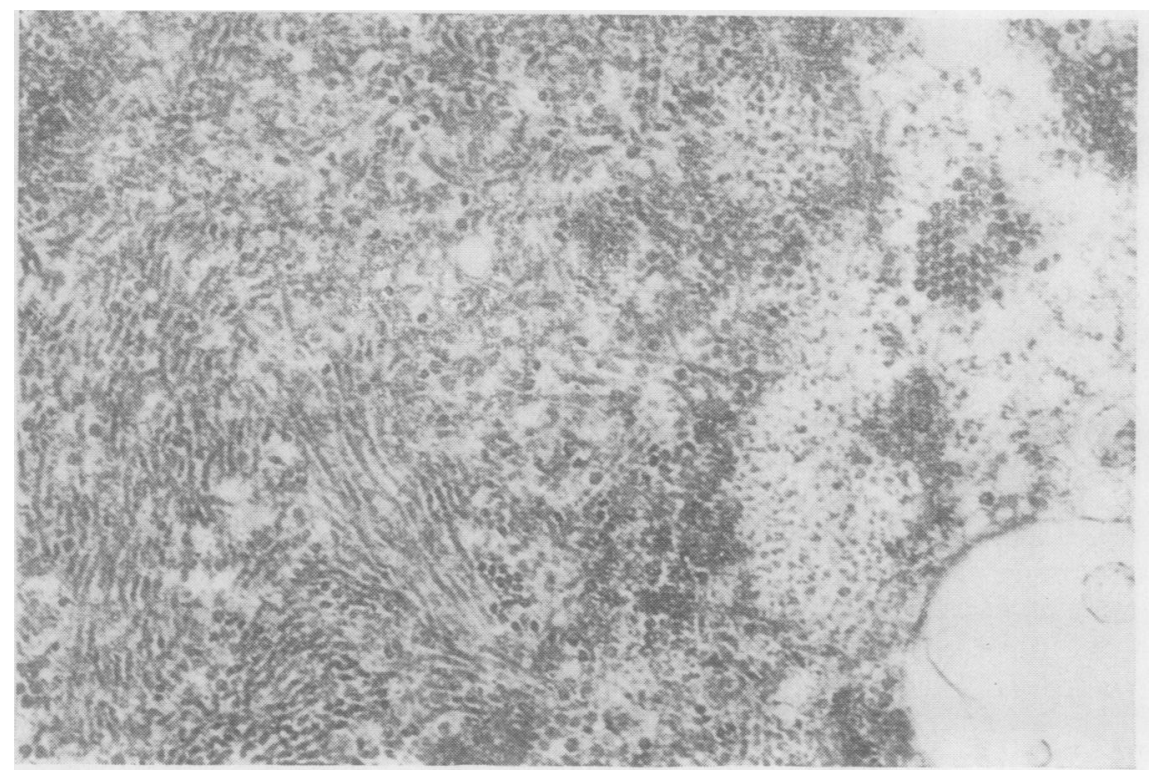

Fig 1 Thin section of progressive multifocal 0 leucoencephalopathyaffected brain. Intranuclear filamentous and spherical polyomavirus particles and intracytoplasmic pseudo-crystalline array of spherical virus particles (nucleus is at the left of the micrograph). $\times 25000$ 


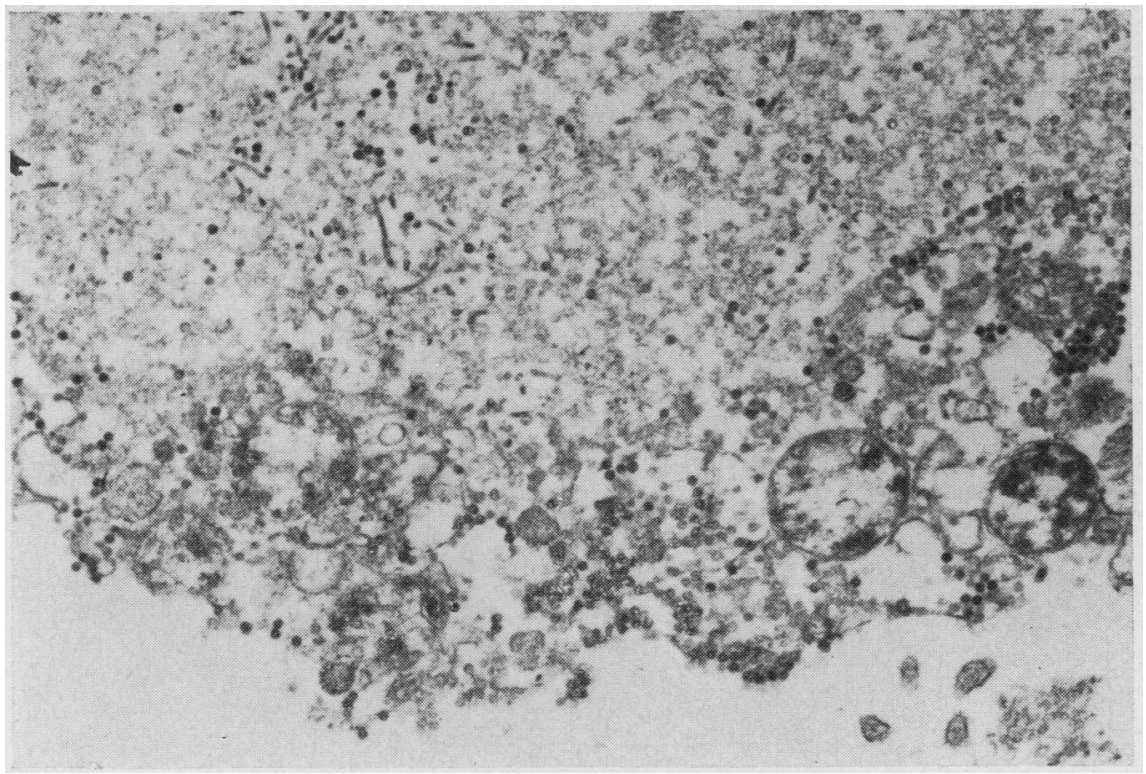

Fig 2 Thin section of foetal brain cell infected in vitro with COL strain. Scattered filamentous and spherical polyomavirus particles in the nucleus (at top of micrograph) and spherical virus particles associated with cell membranes in the cytoplasm. $\times 25000$
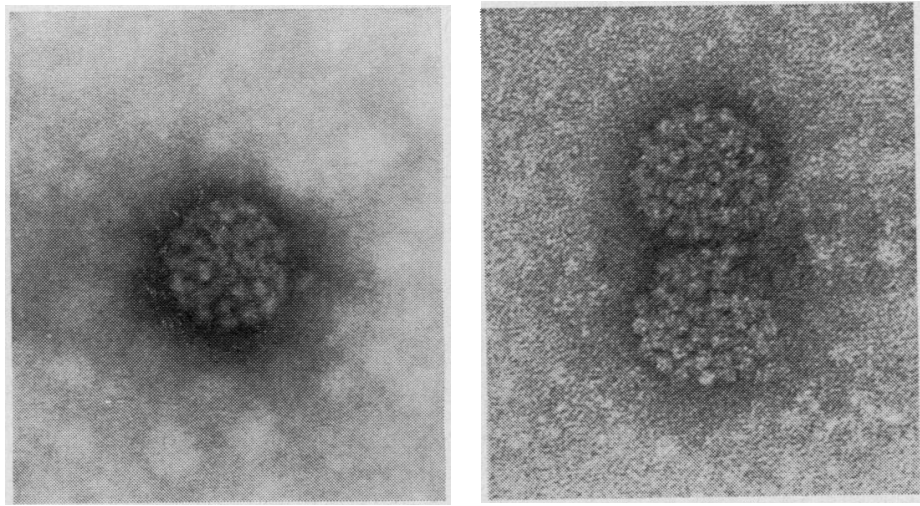

Fig 3

Fig 4

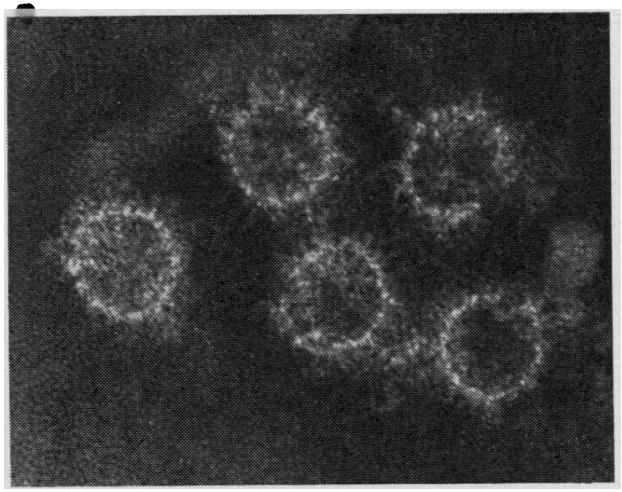

Fig 3 Intact polyomarivus particle from foetal brain culture infected in vitro with $C O L$ strain (negative stain). $\times 252000$

Fig 4 Two disrupted polyomavirus particles from foetal brain culture infected in vitro with COL strain (negative stain). $\times 252000$

Fig 5 Immune electron microscopy: polyomavirus particles of $C O L$ strain agglutinated by antibody in the Fig 5 $J C$ virus antiserum (negative stain). $\times 252000$ 
plasm (fig 1). Glutaraldehyde-fixed brain was homogenized in distilled water and the supernatant fluid mixed with phosphotungstic acid, applied to formvar-carbon-coated grids, and examined for negatively stained virus particles. Spherical particles, $39.1 \mathrm{~nm}$ in diameter, with typical polyomavirus structure were observed.

\section{Materials and Methods}

\section{VIRUS ISOLATION}

Fresh brain tissue obtained at necropsy was transported to the laboratory in sterile containers by post. Explant cultures were made from this material in small petri dishes and these were incubated in an atmosphere of $5 \%$ carbon dioxide. Some of the brain tissue was homogenized and a $10 \%$ brain suspension prepared. This was inoculated directly into Vero and human embryo lung (HEL) fibroblast cell cultures. The remainder of the brain suspension and brain tissue was stored at $-70^{\circ} \mathrm{C}$ until cell cultures of human foetal brain tissue were available for inoculation.

Foetal brain cultures were prepared by trypsinization of brains from 10- to 16-week-old human foetuses. These cells were grown on Eagles (MEM) medium and $10 \%$ foetal calf serum and maintained on the same medium with $3 \%$ foetal calf serum with a twice-weekly fluid change. Subcultures from primary cultures were made at intervals but tube cultures were only used for inoculation when they contained a cell population predominantly of spongioblasts (Shein, 1965). Suitable cultures inoculated with the $10 \%$ extract of brain suspension or passage fluid material were incubated stationary at $37^{\circ} \mathrm{C}$.

ELECTRON MICROSCOPY

Virus-infected human foetal brain cell cultures were fixed in glutaraldehyde, postfixed in osmium tetroxide, and embedded in araldite-epon. Thin sections were stained with uranyl acetate and lead citrate. Fluids from infected cell cultures were centrifuged at $18000 \mathrm{rpm}$ for one hour, the pellets were reconstituted in a drop of distilled water, mixed with phosphotungstic acid, applied to formvar-carboncoated grids and examined for negatively stained virus particles. Viral particle antigens for immune electron microscopy were prepared from the appropriate tissue cultures inoculated with BK virus, $\mathrm{SV}_{40}$ virus, progressive multifocal leucoencephalopathy virus (COL strain), polyoma virus, or rabbit kidney vacuolating virus (RKV): cells and fluids were harvested, ultrasonicated for four minutes, clarified by low speed centrifugation, and the supernatants were centrifuged at $18000 \mathrm{rpm}$ in a Sorvall $\mathrm{RC} 2 \mathrm{~B}$ centrifuge for one hour. $\mathrm{K}$ virus was extracted from $0.3 \mathrm{ml}$ infected mouse liver suspension by ultrasonication in $2 \mathrm{ml}$ phosphate-buffered saline followed by low and high speed centrifugation. The pellets were reconstituted in phosphate-buffered saline so that when used as antigen in the immune electron microscopy test there were 10 to 50 virus particles per grid square; this approximated to a concentration of $10^{9}$ to $10^{10}$ particles per $\mathrm{ml}$ of antigen. The immune electron microscopy test was performed by mixing $0.1 \mathrm{ml}$ antigen with $0.1 \mathrm{ml}$ antiserum diluted in phosphate-buffered saline, the mixtures were incubated for 90 minutes at room temperature and overnight at $4^{\circ} \mathrm{C}$, then $2 \mathrm{ml}$ cold phosphate-buffered saline was added to each mixture and the whole centrifuged at $12000 \mathrm{rpm}$ for one hour. Pellets were reconstituted in distilled water for negative staining as described above. The presence of visible antibody molecules between aggregated virus particles indicated a positive antibody reaction which was graded + to ++++ according to the amount of antibody present in the aggregates.

\begin{tabular}{|c|c|c|c|c|c|c|c|c|}
\hline \multirow[t]{3}{*}{ Virus } & \multicolumn{4}{|l|}{ BK Sera } & \multicolumn{4}{|c|}{ PML Sera } \\
\hline & \multicolumn{2}{|c|}{ BK Patient's Serum ${ }^{1}$} & \multicolumn{2}{|c|}{ BK Antiserum } & \multicolumn{2}{|c|}{ Patient's Serum ${ }^{1}$} & \multicolumn{2}{|c|}{ JC Antiserum } \\
\hline & $1 / 10$ & $1 / 30$ & $1 / 10$ & $1 / 30$ & $1 / 10$ & $1 / 30$ & $1 / 10$ & $1 / 30$ \\
\hline $\begin{array}{l}\text { BK } \\
\text { Progressive multifocal }\end{array}$ & $++t$ & $++t+$ & $+t+$ & $++t$ & + & - & - & - \\
\hline leucoencephalopathy (COL strain) & NT & NT & - & - & $+++t$ & $+t$ & +++ & $+t+$ \\
\hline$S_{40}$ & + & - & - & - & - & - & - & - \\
\hline Polyoma & - & NT & - & NT & - & NT & NT & NT \\
\hline $\mathbf{K}$ & - & NT & - & NT & - & NT & NT & NT \\
\hline RKV & - & NT & - & NT & - & NT & NT & NT \\
\hline
\end{tabular}

Table Antigenic relationships in the Polyomavirus genus by immune electron microscopy

${ }^{1}$ Sera from the two patients from whom BK virus and COL virus were isolated

+ to ++++ are increasing amounts of antibody in aggregates of virus particles 
VIRUSES AND ANTISERA

$\mathrm{BK}$ and $\mathrm{SV}_{40}$ viruses were grown in Vero cells. The BK antiserum was made in guinea-pigs. The following viruses and antisera were kindly provided: $\mathrm{SV}_{40}$ hyperimmune calf serum by $\mathrm{Mr} \mathrm{J}$. Hill (Pfizer Ltd); JC guinea-pig antiserum by Dr B. Padgett (University of Wisconsin); polyoma virus and antiserum by Dr L. V. Crawford (Imperial Cancer Research Fund); $\mathrm{K}$ virus mouse liver suspension and mouse antiserum by Dr J. C. Parker (Microbiological Associates) and RKV strain 443 and RKV rabbit antiserum by Dr W. P. Rowe (National Institute of Allergy and Infectious Diseases, Bethesda). RKV was grown in primary rabbit kidney cells.

\section{Results}

\section{PROGRESSIVE MULTIFOCAL}

LEUCOENCEPHALOPATHY VIRUS ISOLATION Initially no cytopathic changes were obvious in the foetal brain cultures. After an incubation period of two months moderate numbers of polyomavirus particles were seen by electron microscopy after high-speed centrifugation of pooled culture fluids from the inoculated but not the control cultures. Approximately two weeks later definite small vacuoles appeared in the spongioblast areas of the cultures. This effect, which was not seen in control cells even after prolonged incubation periods, could be transmitted to fresh brain cultures and was always associated with the presence of virus particles in the culture fluid as demonstrated by electron microscopy. Highly refractile single cells scattered over the cell sheet were also frequently observed. Although these cytopathic changes were minimal they were specific and were useful in selecting culture fluids suitable for electron microscopy.

The inoculated brain cells slowly continued to produce small amounts of infectious virus over long periods but on passage no virus particles appeared in the culture fluid before about four weeks. It has not been possible to adapt the virus to grow in Vero or HEL fibroblast cells and no haemagglutinin for human erythrocytes has been demonstrated. No virus was isolated by direct inoculation of the original brain material into Vero or HEL cell cultures nor was it possible to establish a cell line from the explant cultures of the brain tissue.

\section{ELECTRON MICROSCOPY OF PROGRESSIVE MULTIFOCAL LEUCOENCEPHALOPATHY VIRUS-INFECTED FOETAL BRAIN CULTURES} Approximately $10 \%$ of the cells in the thin sections of inoculated foetal brain cultures were infected with polyomavirus particles. The round virus particles (average diameter $43.4 \mathrm{~nm}$ ) were scattered throughout the nuclei of infected cells. Filamentous forms, $23.0 \mathrm{~nm}$ across, were occasionally seen in nuclei. Round particles were also observed in the cell cytoplasm usually in close association with cytoplasmic membranes (fig 2).

Negatively stained virus particles had typical polyomavirus morphology (fig 3). They ranged in diameter from 38.2 to $56.9 \mathrm{~nm}$, average $49.3 \mathrm{~nm}$. The larger particles were often broken open and appeared incomplete (fig 4).

\section{IMMUNE ELECTRON MICROSCOPY}

Results of immune electron microscopy tests on the newly isolated COL strain of progressive multifocal leucoencephalopathy virus and five other viruses of the Polyomavirus genus using appropriate antisera and the patient's serum are shown in the table.

The COL strain was agglutinated by JC antiserum but not by BK antiserum (fig 5). All viruses were strongly agglutinated by the homologous antiserum. In all cases low serum dilutions $(1 / 10$ to $1 / 30)$ gave ++++ or +++ reactions with the homologous virus. The homologous antibody titres, determined by diluting the antisera and using a

\begin{tabular}{|c|c|c|c|c|c|}
\hline \multicolumn{2}{|c|}{$S V_{40}$ Antiserum } & \multicolumn{2}{|c|}{ Polyoma Antiserum } & \multirow{2}{*}{$\frac{\mathrm{K} \text { Antiserum }}{1 / 5}$} & \multirow{2}{*}{$\frac{R K V \text { Antiserum }}{1 / 10}$} \\
\hline $1 / 10$ & $1 / 30$ & $1 / 10$ & $1 / 30$ & & \\
\hline+ & - & - & $\mathbf{N T}$ & - & - \\
\hline $\begin{array}{l}++ \\
++++ \\
- \\
\pm \\
\pm\end{array}$ & $\begin{array}{l} \pm \\
\stackrel{+}{+}+++ \\
\text { NT } \\
\text { NT } \\
\text { NT }\end{array}$ & $\begin{array}{l}\overline{-} \\
++++ \\
-\end{array}$ & $\begin{array}{l}\text { NT } \\
\text { NT } \\
++++ \\
\text { NT } \\
\text { NT }\end{array}$ & $\begin{array}{l}- \\
\text { NT } \\
\text { NT } \\
++++ \\
\text { NT }\end{array}$ & $\begin{array}{l}-\overline{N T} \\
\text { NT } \\
\text { NT } \\
++++\end{array}$ \\
\hline
\end{tabular}

Table continued

\pm traces of antibody-like substance attached to individual particles or in aggregates

- no antibody molecules attached to particles. NT not tested 
constant virus dose in the immune electron microscopy test, were expressed as the highest dilutions to give a + positive reaction. Homologous titres of the sera used were: BK patient's serum $1 / 1280$, BK guinea-pig antiserum $1 / 240$, the patient's serum $>1 / 30, \mathrm{SV}_{40}$ antiserum $1 / 640$, polyoma antiserum $1 / 1280$, $K$ virus antiserum $>1 / 50$, and $R K V$ antiserum $>1 / 10$.

The hyperimmune calf $\mathrm{SV}_{40}$ antiserum used cross reacted slightly at low dilution with all members of the group except polyoma virus. There was some evidence for the reciprocal reaction between $\mathrm{BK}$ antibody and $\mathrm{SV}_{40}$ virus using $\mathrm{BK}$ patient's serum. The progressive multifocal leucoencephalopathy patient's serum at low dilution gave a small + antibody reaction with BK virus. The haemagglutination inhibition titre of the same serum with BK virus was $1 / 160$. The guinea-pig serum raised against $\mathrm{JC}$ virus strongly aggregated the COL strain but had no reaction with $\mathrm{BK}$ or $\mathrm{SV}_{40}$ viruses. No other cross reactions were noted.

\section{Discussion}

The polyomavirus isolated from brain tissue of a patient with progressive multifocal leucoencephalopathy was designated COL strain. It grew in cultured human foetal brain cells but not in Vero or HEL cell cultures. This property placed $\mathrm{COL}$ closer to the JC polyomavirus, similarly isolated from a progressive multifocal leucoencephalopathy brain, than to other polyomaviruses recently recovered from human subjects: BK virus from urines and the $\mathrm{SV}_{40}$-related viruses from two other progressive multifocal leucoencephalopathy-affected brains. A haemagglutinin for human 0 erythrocytes has been described for BK virus (Gardner et al, 1971) and JC virus (Padgett and Walker, 1973) but not for $\mathrm{SV}_{40}$ or the two human $\mathrm{SV}_{40}$-related viruses. Absence of haemagglutinin in this new progressive multifocal leucoencephalopathy isolate may be due to a low virus yield from the brain cultures. JC virus infected $50 \%$ of cultured brain cells (Padgett et al, 1971) whereas only $10 \%$ were infected with the COL strain.

The vacuolated appearance of infected human foetal brain cells was a consistent feature of the cytopathic effect caused by the COL strain and has not previously been described for human polyomaviruses in these cells except at the ultrastructural level (Padgett et al, 1971). Two strains of BK virus isolated in this laboratory from urines in foetal brain cells gave a similar but more extensive cytopathic appearance. Both $\mathrm{SV}_{40}$ and RKV cause vacuolation of the cytoplasm in vitro. This may prove to be an important polyomavirus group property.
Ultrastructurally the new isolate is clearly a member of the Polyomavirus genus. It occurred mainly as filaments in the infected brain but in foetal brain cells the spherical particles predominated. Conditions in cell culture were clearly not ideal for virus replication since over half the particles were broken open and in consequence were slightly larger than is usual for this group.

Immune electron microscopy tests on the complete range of viruses in the Polyomavirus genus revealed that $\mathrm{COL}$ was closely related antigenically to JC human polyomavirus but was distinct from other members of the group except $\mathbf{S V}_{40}$ where there was a slight cross reaction. It appeared that the hyperimmune $\mathrm{SV}_{40}$ antiserum used for these tests had a broad spectrum of antibodies and cross reacted to some degree with all the heterologous polyomaviruses with the exception of mouse polyoma virus, the type member of the genus. It is possible that there is a group antigen present in small quantity in these polyomaviruses as well as a large amount of type-specific antigen. Two surface antigens have been found on $\mathbf{S V}_{\mathbf{4 0}}$ particles (Koch, Becht, and Anderer, 1971; Margalith, Margalith, and Spira, 1972). Penney and Narayan (1973) have observed that hyperimmune sera give marked serological cross reactions between $\mathrm{SV}_{\mathbf{4 0}}, \mathrm{BK}$, and another JC-like polyomavirus but tests using early immune sera show little relationship between these viruses. Some $\mathbf{S V}_{40}$ sera cross react slightly with JC virus while others show no cross reaction (Padgett and Walker, 1973) and similar variation of cross reactivity between different $\mathbf{S V}_{\mathbf{4 0}}$ antisera and BK virus has been noted in this laboratory (Gardner and Field, unpublished observations). We found it essential to use a rigidly standardized virus dose in the immune electron microscopy test in order to obtain reproducible results and to make valid comparisons between viruses and antibody titres.

The patient from whose brain this new polyomavirus was isolated had antibody to the agent. He had no antibody to other polyomaviruses with the exception of BK virus to which he had a low titre of antibody. The mere presence either of JC or BK virus antibodies has little significance since 60 to $70 \%$ of normal adults have these antibodies (Padgett and Walker, 1973; Gardner, 1973). Amako and Mori (1972) used polyomavirus particles extracted from a progressive multifocal leucoencephalopathy brain and found their patient had antibody to the virus but had no antibody to $\mathrm{SV}_{40}$ or mouse polyoma virus.

It appears from the results of these cross tests that the Polyomavirus genus can now be considered to contain at least six distinct antigenic types: polyoma virus of mice (the type member of the genus), $\mathrm{K}$ virus of mice, RKV of rabbits, $\mathbf{S V}_{40}$ of monkeys, 
BK virus of human subjects and JC virus of human subjects. The newly isolated COL polyomavirus is a further strain of JC virus. The classification position of the $\mathbf{S V}_{\mathbf{4 0}}$-like viruses isolated from two patients with progressive multifocal leucoencephalopathy is at present unclear: antigenically and biologically they are identical with $\mathbf{S V}_{40}$ (Weiner et al, 1972; Penney, Weiner, Herndon, Narayan, and Johnson, 1972; Penney and Narayan, 1973) yet the nucleic acid has subtle differences from $\mathbf{S V}_{\mathbf{4 0}}$ nucleic acid (Sack, Narayan, Danna, Weiner, and Nathans, 1973). A porcine polyomavirus has been described (Newman and Smith, 1972) but its relationship with other members of the group has yet to be established.

The polyomaviruses isolated from brains of patients with progressive multifocal leucoencephalopathy so far fall into two types. The majority of isolates are strains of JC virus: Padgett and her colleagues (1971) recorded the original isolation of JC, a second strain was isolated by Weiner, Narayan, Penney, Herndon, Feringa, Tourtellotte, and Johnson (1973), and this paper records the third isolation of a JC strain. More recently in this laboratory a further (fourth) strain of JC polyomavirus has been isolated from brain biopsy material from a patient with progressive multifocal leucoencephalopathy (Gardner and Field, unpublished observations). The second type associated with this disease includes the two strains of $\mathrm{SV}_{40}$ virus (Weiner et al, 1972). Serological surveys have shown that more than twothirds of American adults have antibody to JC virus. It has not yet been possible to do a similar survey for JC antibody in Great Britain but it has been found that three-quarters of the adult population have BK virus antibody. With the exception of special groups $\mathbf{S V}_{40}$ antibody is uncommon in man (Shah, 1972). BK virus has not yet been implicated in any pathological condition. JC virus undoubtedly occurs in association with progressive multifocal leucocencephalopathy both in the United States of America and the United Kingdom.

We are grateful to Dr P. K. Robinson, consultant neurologist at Southampton General Hospital, for permission to publish this case; to Dr H. E. M. Kay and Dr S. D. Lawler of the foetal tissue bank at the Royal Marsden Hospital for human foetal brains, and to Mr A. A. Porter for preparing the electron micrographs.
References

Amako, K., and Mori, R. (1972). Serological and morphological studies on progressive multifocal leucoencephalopathy virus. Jap. J. Microbiol., 16, 155-158.

Coleman, D. V., Gardner, S. D., and Field, A. M. (1973). Human polyomavirus infection in renal allograft recipients. Brit. med. J., 3, 371-375.

Gardner, S. D. (1973). Prevalence in England of antibody to human polyomavirus (B.K.). Brit. med. J., 1, 77-78.

Gardner, S. D., Field, A. M., Coleman, D. V., and Hulme, B. (1971). New human papovavirus (B.K.) isolated from urine after renal transplantation. Lancet, 1, 1253-1257.

International Committee on Nomenclature of Viruses (1971). Classification and nomenclature of viruses: first report. Monogr. Virol., 5, 39.

Koch, M. A., Becht, H., and Anderer, F. A. (1971). Structure of simian virus 40 . V. Localization of the C-type polypeptide chains. Virology, 43, 235-242.

Margalith, M., Margalith, E., and Spira, G. (1972). On the nature of the $\mathrm{SV}_{\mathbf{4 0}}$ viral antigen induced in $\mathbf{B S C}_{\mathbf{1}}$ transformed cells. Arch. ges. Virusforsch., 36, 398-400.

Newman, J. T., and Smith, K. O. (1972). Characteristics of a swine papova virus. Infect. and Immun., 5, 961-967.

Padgett, B. L., and Walker, D. L. (1973). Prevalence of antibodies in human sera against JC virus, an isolate from a case of progressive multifocal leukoencephalopathy. J. infect. Dis., 127, 467-470.

Padgett, B. L., Walker, D. L., ZuRhein, G. M., and Eckroade, R. J. (1971). Cultivation of papova-like virus from human brain with progressive multifocal leucoencephalopathy. Lancet, 1, $1257-1260$.

Penney, J. B., and Narayan, O. (1973). Studies of the antigenic relationships of the new human papovaviruses by electron microscopy agglutination. Infect. and Immun., 8, 299-300.

Penney, J. B., Jr., Weiner, L. P., Herndon, R. M., Narayan, O., and Johnson, R. T. (1972). Virions from progressive multifocal leukoencephalopathy: rapid serological identification by electron microscopy. Science, 178, 60-62.

Sack, G. H., Jr., Narayan, O., Danna, K. J., Weiner, L. P., and Nathans, D. (1973). The nucleic acid of an SV40-like virus isolated from a patient with progressive multifocal leukoencephalopathy. Virology, 51, 345-350.

Shah, K. V. (1972). Evidence for an SV40-related papovavirus infection of man. Amer. J. Epidemiol., 95, 199-206.

Shein, H. M. (1965). Propagation of human fetal spongioblasts and astrocytes in dispersed cell cultures. Exp. Cell Res., 40, 554-569.

Weiner, L. P., Herndon, R. M., Narayan, O., Johnson, R. T., Shah, K., Rubinstein, L. J., Preziosi, T. J., and Conley, F. K. (1972). Isolation of virus related to SV40 from patients with progressive multifocal leukoencephalopathy. New Engl. J. Med., 286, 385-390.

Weiner, L. P., Narayan, O., Penney, J. B., Herndon, R. M., Feringa, E. R., Tourtellotte, W. W., and Johnson, R. T. (1973). Papovavirus of JC type in progressive multifocal leucoencephalopathy. Arch. Neurol., 29, 1-3.

ZuRhein, G. M., and Chou Shi-Ming (1965). Particles resembling papovaviruses in human cerebral demyelinating disease. Science, 148, 1477-1479.

\section{Addendum}

Since this paper was written nine more strains of JC virus have been identified in progressive multifocal leucoencephalopathy brains by immune electron microscopy using virus extracted from the brains (Narayan et al, New Engl. J. Med. (1973), 289, 1278). Five were from residents of the United States of America, two were from Canada, and two were from France. 